\title{
Technical note \\ Evolution of operational parameters in a UASB wastewater plant
}

\author{
SMB Barbosa Correa ${ }^{1 *}$, E Ruiz ${ }^{2}$ and F Romero ${ }^{2}$ \\ ${ }^{1}$ Pontificia Universidade Católica, PoVos de Caldas, Minas Gerais, Brazil \\ ${ }^{2}$ Dpto. de Ingeniería Química y del Medio Ambiente, Escuela Superior de Ingenieros, Alameda de Urquijo s/n, 48013, Bilbao, Spain
}

\begin{abstract}
The results reported here are based on data of the Nova Pampulha Wastewater Treatment Plant, in the metropolitan region of Belo Horizonte (Minas Gerais, Brazil) containing an upflow anaerobic sludge blanket (UASB) reactor. The objective of this research was to establish the operational parameters of the plant and evolution of elimination of pollutants. Influent and effluent parameters used for this research, were oils, volatile fatty acidity, alkalinity, ammonium, bacteria, flow, chlorides, BOD, detergents, COD, phosphates, total nitrogen, $\mathrm{pH}$, settleable solids, suspended solids (total and volatile), sulphates, sulphides, temperature (air, influent, effluent and reactor) and hydraulic retention time (HRT). Weekly data were collected between January 1998 and June 2000, namely 124 weeks. Methods used for data included conventional statistics, graphical representations and multiple linear regression, applied with the program SPSS, licensed to UPV/EHU with the aim of obtaining equations for the estimation of\%age elimination (or increase) of pollutants during anaerobic treatment. The analysis of operational data of the Nova Pampulha plant also includes the temporary and seasonal evolution of control parameters, made by a set of graphical representations for process parameters (flow, HRT, temperature and bacterial count), parameters associated with acid - base equilibrium (acidity, alkalinity and $\mathrm{pH}$ ), organic constituents (BOD, COD, oils and detergents), inorganic constituents chlorides, phosphates, sulphates, sulphides and nitrogen compounds) and solids (settleable and suspended). By using multiple linear regression, equations could be obtained for estimating the elimination of constituent loads as functions of process parameters and constituent loads in the influents, as possible independent variables. Equations, statistically significant at a $95 \%$ confidence level, were obtained for all the eliminations. The calculation is presented in the form of regression equations and some comparative graphics between experimental and predicted data. Data variances were in the region of 20 and $87 \%$. The observation of coefficients of equations for organic matter and suspended solids permits the establishment of parameters associated with elimination or increase of these constituents.
\end{abstract}

Keywords: wastewater, anaerobic treatment, UASB reactor, percentage elimination of pollutants

\section{Introduction}

Of the techniques used for the anaerobic treatment of wastewater, the UASB (upflow anaerobic sludge blanket) reactor is actually a technology adapted for a wide variety of industrial effluents and wastewater (Lettinga et al., 1997; Lópèz and Iza, 1998). Furthermore, it is very well suited to the climatic conditions of Brazil (Von Sperling, 1995; Van Haandel and Lettinga, 1994).

The efficiency of the system has been proved and the results obtained fulfil the objectives intended in well-designed and -operated plants. This type of reactor treats domestic wastewater with $500 \mathrm{mg} / \ell$ BOD eliminating $80 \%$ of the organic load in stations of Large Campina-Paraiba (Van Haandel et al., 1993) and São Paulo (Vieira et al., 1994).

In Brazil the number of cities and industries with wastewater treatment plants is very limited. Wastewater is collected in about $30 \%$ of the towns and villages, and treatment plants are found in only $10 \%$ of them (Chernicharo, 1997; Fundacao,2000). One of the factors that prevent a most effective development is the territorial expanse, as well as the population distribution (170 million inhabitants).

In this work real data from Nova Pampulha, a community of

\footnotetext{
* To whom all correspondence should be addressed.

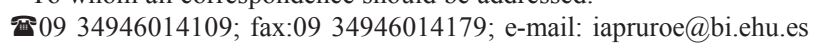
Received 29 July 2002; accepted in revised form 21 March 2003.
}

6600 inhabitants, located in Ribeirão das Neves, a residential area of the metropolitan region of Belo Horizon, was used. The wastewater treatment plant, owned by Companhia de Saneamento of Minas Gerais, COPASA-MG, uses a UASB reactor for biological treatment. Information obtained was used for the following purposes:

- to analyse the operational data of the plant, in order to determine the removal efficiency of pollutants, and its relation with process, temporal and seasonal parameters, and

- to obtain mathematical equations that allow the estimation of pollutant removal by the anaerobic digestion process used in the plant for different experimental conditions.

\section{Experimental}

\section{Description of the plant}

The water treatment plant in Nova Pampulha includes the following stages:

- Pumping of urban wastewater (maximum flow rate $43 \mathrm{~m}^{3} / \mathrm{h}$ and $25 \mathrm{~m}$ of water column). The impulse pipe comprises $200 \mathrm{~mm}$ diameter PVC tubes and leads to a channel.

- Screening by $12.5 \mathrm{~mm}$ back racks with manual cleaning.

- Grit removal in a $5.0 \mathrm{~m}$ settling tank. 
TABLE 1

Mean values, standard deviations, variation coefficients and range of parameters

\begin{tabular}{|c|c|c|c|c|c|c|}
\hline \multirow{2}{*}{ Parameters } & \multirow{2}{*}{ Units } & \multirow{2}{*}{ Mean } & \multirow{2}{*}{$\sigma$} & \multicolumn{2}{|c|}{ Range } & \multirow{2}{*}{ CV } \\
\hline & & & & Minima & Maxima & \\
\hline Oil (eff.) & $\mathrm{kg} / \mathrm{d}$ & 63.48 & 38.05 & 21.57 & 205.19 & 59.94 \\
\hline Oil (inf.) & $\mathrm{kg} / \mathrm{d}$ & 96.80 & 51.57 & 6.59 & 293.31 & 53.27 \\
\hline Acidity (eff.) & $\mathrm{kg} \mathrm{AcH} / \mathrm{d}$ & 47.80 & 21.32 & 10.07 & 120.23 & 44.60 \\
\hline Acidity (inf.) & $\mathrm{kg} \mathrm{AcH} / \mathrm{d}$ & 44.80 & 20.67 & 7.78 & 125.14 & 46.14 \\
\hline Alkalinity (eff.) & $\mathrm{kgCO}_{3} \mathrm{Ca} / \mathrm{d}$ & 270.65 & 85.61 & 59.93 & 441.5 & 31.63 \\
\hline Alkalinity (inf.) & $\mathrm{kgCO}_{3} \mathrm{Ca} / \mathrm{d}$ & 223.49 & 94.91 & 13.51 & 633.27 & 42.47 \\
\hline Flow & $\mathrm{m}^{3} / \mathrm{d}$ & 983 & 213 & 458 & 1322 & 21.70 \\
\hline Bacteria (eff.) & number/d & $1.43 \mathrm{E}+16$ & $6.35 \mathrm{E}+16$ & $1.18 \mathrm{E}+09$ & $2.92 \mathrm{E}+17$ & 444.34 \\
\hline Bacteria (inf.) & number/d & $1.70 \mathrm{E}+16$ & $6.83 \mathrm{E}+16$ & $1.65 \mathrm{E}+12$ & $3.15 \mathrm{E}+17$ & 401.06 \\
\hline Chloride (eff.) & $\mathrm{kg} / \mathrm{d}$ & 58.86 & 21.13 & 24.62 & 107.31 & 35.90 \\
\hline Chloride (inf.) & $\mathrm{kg} / \mathrm{d}$ & 60.44 & 20.76 & 26.83 & 107.22 & 34.35 \\
\hline BOD (eff.) & $\mathrm{kg} / \mathrm{d}$ & 102.92 & 56.86 & 30.41 & 374.7 & 55.25 \\
\hline BOD (inf.) & $\mathrm{kg} / \mathrm{d}$ & 328.75 & 127.94 & 125.09 & 724.2 & 38.92 \\
\hline Detergents (inf.) & $\mathrm{kg} / \mathrm{d}$ & 9.63 & 4.08 & 1.04 & 20.18 & 42.37 \\
\hline COD (eff.) & $\mathrm{kg} / \mathrm{d}$ & 279.35 & 133.42 & 44.82 & 834.67 & 47.76 \\
\hline COD (inf.) & $\mathrm{kg} / \mathrm{d}$ & 649.18 & 239.99 & 159.07 & 1408.91 & 36.97 \\
\hline Phosphate (eff.) & $\mathrm{kg} / \mathrm{d}$ & 5.11 & 2.86 & 0.76 & 12.49 & 55.97 \\
\hline Phosphate In & $\mathrm{kg} / \mathrm{d}$ & 5.01 & 2.66 & 1.84 & 13.88 & 53.09 \\
\hline N-NH 3 (eff.) & $\mathrm{kg} / \mathrm{d}$ & 40.25 & 13.20 & 8.64 & 78.78 & 32.80 \\
\hline $\mathrm{N}^{-\mathrm{NH}_{3}}$ (inf.) & $\mathrm{kg} / \mathrm{d}$ & 29.96 & 12.66 & 7.98 & 63.71 & 42.26 \\
\hline N-Total (eff.) & $\mathrm{kg} / \mathrm{d}$ & 48.09 & 16.63 & 12.9 & 96.17 & 34.58 \\
\hline N-Total (inf.) & $\mathrm{kg} / \mathrm{d}$ & 44.81 & 26.46 & 15.56 & 171.82 & 59.05 \\
\hline SSet (eff.) & $\mathrm{kg} / \mathrm{d}$ & 0.82 & 0.88 & 0.21 & 8.89 & 107.32 \\
\hline SSet (inf.) & $\mathrm{kg} / \mathrm{d}$ & 5.06 & 1.23 & 2.23 & 7.81 & 24.31 \\
\hline FSS (eff.) & $\mathrm{kg} / \mathrm{d}$ & 34.53 & 28.39 & 3.00 & 193.00 & 91.03 \\
\hline FSS (inf.) & $\mathrm{kg} / \mathrm{d}$ & 47.11 & 24.06 & 4.00 & 122.00 & 54.91 \\
\hline TSS (eff.) & $\mathrm{kg} / \mathrm{d}$ & 122.29 & 102.89 & 8.94 & 523.62 & 84.14 \\
\hline TSS (inf.) & $\mathrm{kg} / \mathrm{d}$ & 203.61 & 111.68 & 26.83 & 586.07 & 54.85 \\
\hline VSS (eff.) & $\mathrm{kg} / \mathrm{d}$ & 83.75 & 84.16 & 3.94 & 398.72 & 100.49 \\
\hline VSS (inf.) & $\mathrm{kg} / \mathrm{d}$ & 160.59 & 98.64 & 9.69 & 515.21 & 61.42 \\
\hline Sulphate (inf.) & $\mathrm{kg} / \mathrm{d}$ & 46.18 & 19.16 & 7.02 & 115.21 & 41.49 \\
\hline Sulphide (inf.) & $\mathrm{kg} / \mathrm{d}$ & 0.047 & 0.050 & 0.010 & 0.286 & 106.38 \\
\hline $\mathrm{pH}$ (eff.) & units & 6.63 & 0.10 & 6.20 & 7.00 & 1.51 \\
\hline pH (inf.) & units & 7.09 & 0.16 & 6.50 & 7.90 & 2.26 \\
\hline pH Rea & units & 6.63 & 0.10 & 6.10 & 7.00 & 1.51 \\
\hline Temp. air & ${ }^{\circ} \mathrm{C}$ & 23.8 & 1.8 & 19.5 & 28.0 & 7.74 \\
\hline Temp. (eff.) & ${ }^{\circ} \mathrm{C}$ & 24.4 & 1.7 & 21.0 & 28.0 & 6.84 \\
\hline Temp. (inf.) & ${ }^{\circ} \mathrm{C}$ & 24.4 & 1.7 & 21.0 & 28.0 & 6.88 \\
\hline Temp. Rea & ${ }^{\circ} \mathrm{C}$ & 24.5 & 1.7 & 22.0 & 28.0 & 7.03 \\
\hline HRT & $\mathrm{h}$ & 7.76 & 2.32 & 5.41 & 15.62 & 29.90 \\
\hline
\end{tabular}

- Control of flow by $3 \mathrm{~mm}$ Parshall flume.

- A distribution system formed by triangular notch weirs, which divide the flow into two equal parts to the bottom of the reactor through two $150 \mathrm{~mm}$ diameter tubes. Each tube has eight radial outlets.

- A UASB biological reactor operating at ambient temperature. The reactor, made from brick and concrete, has a horizontal area of $39 \mathrm{~m}^{2}$, a depth of $5.65 \mathrm{~m}$ and two chambers, each one with a volume of $149 \mathrm{~m}^{3}$. The cone-shaped internal settler has a volume close to $6.9 \mathrm{~m}^{3}$, a height of $1.10 \mathrm{~m}$ and an upper section of $12.70 \mathrm{~m}^{2}$.

- A cascade gravity aerator

- Two sand-bed sludge dryers.

\section{Sampling and control parameters}

Sampling and determination of control parameters, used in this research on the Nova Pampulha wastewater plant were carried out by COPASA, between January 1998 and June 2000, in the following manner:

Twice a day, approximately at 09:00 and 15:00h, temperatures, $\mathrm{pH}$ values and settleable solids were measured in situ. Flow was measured each hour and expressed as $l / \mathrm{s}$. The data obtained were averaged to get weekly values in each case. From the weekly flow data and reactor volumes $\left(298 \mathrm{~m}^{3}\right)$, hydraulic retention times (HRT) were calculated and expressed in hours. 

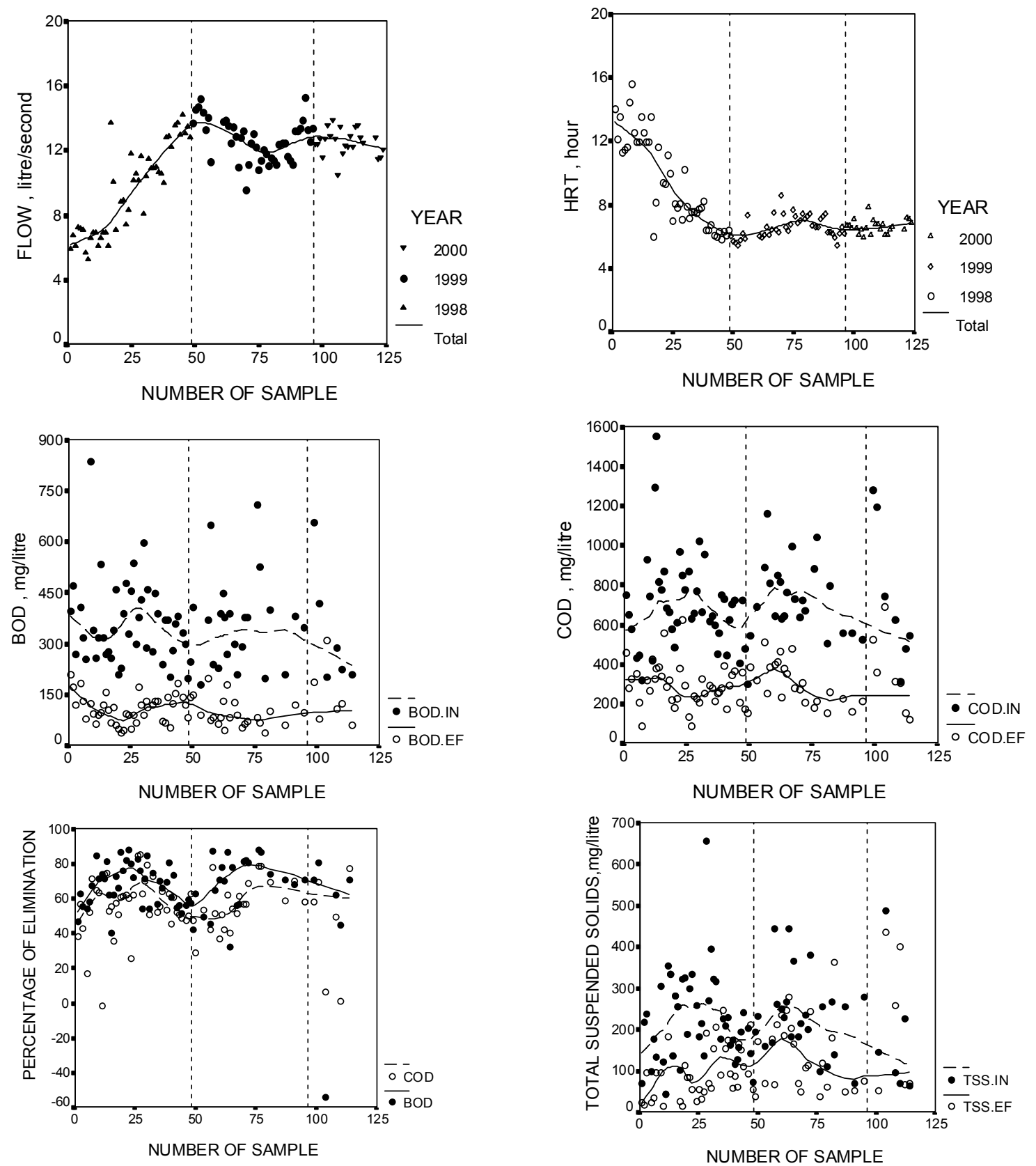

Figure 1

Temporal evolution of some parameters

To determine the rest of the operational parameters, a composite sample was made up by $200 \mathrm{~m} \ell$ aliquots, taken every hour of the day and preserved in a closed plastic vessel at a temperature of $5^{\circ} \mathrm{C}$. Sampling was done weekly and used to measure, according to Standard Methods (1999), the following parameters: oils, volatile fatty acids, alkalinity, ammonia nitrogen, bacteria, chlorides, BOD, detergents, COD, phosphates, Kjeldahl total nitrogen, settleable solids, suspended solids (total and volatile), sulphates and sulphides.

From the analysis results, the constituent loads were calculated and expressed as $\mathrm{kg} / \mathrm{d}$. In the case of bacteria, data were finally expressed as number of bacteria/d. The percentages of elimination of constituents were obtained from individual influent and effluent data.

\section{Data treatment}

The methods used include conventional statistics (Calvo, 1978), X - Y graphs and a multivariate statistical method (multiple linear regression), applied with the program SPSS, licensed to UPV/EHU (SPSS, 1989-93), the applications of which are described by Ferrán (1996).

The conventional statistics used were the following: Mean value, standard deviation, maximum and minimum values and percentage of variability $(\mathrm{CV}=100 \mathrm{x}$ standard deviation $/$ mean value). In multiple linear regression, the elimination of a constituent load was related to other parameters, taken as independent variables, by means of a linear equation of the type:

$$
\mathrm{Y}=\mathrm{a}+\mathrm{b} \mathrm{X}_{1}+\mathrm{c} \mathrm{X}_{2}+\mathrm{d} \mathrm{X}_{3}+\ldots
$$


TABLE 2

Average values of percentages of elimination of constituent loads

\begin{tabular}{|l|c|c|c|c|c|}
\hline Constituent & Mean & Std deviation & Minimum & Maximum & \% CV \\
\hline Oil & 18.31 & 101.54 & -700 & 70.88 & 555 \\
Acidity & -15.64 & 45.8 & -171.43 & 58.33 & -293 \\
Alkalinity & -56.67 & 201.19 & -1443.48 & 43.93 & -355 \\
Bacteria & 36.84 & 102.22 & -320 & 100 & 278 \\
Chloride & 2.89 & 10.31 & -18.18 & 27.78 & 357 \\
BOD & 66.42 & 19.8 & -53.69 & 89.3 & 29.8 \\
COD & 55.54 & 17.39 & -0.94 & 85.85 & 31.3 \\
Phosphate & -2.43 & 24.21 & -72.22 & 74.47 & -996 \\
N-NH & -52.54 & 68.04 & -281.4 & 82.37 & -130 \\
N-Total & -21.09 & 41.08 & -171.43 & 76.41 & -195 \\
SSet & 84.61 & 12.66 & -32.08 & 93.42 & 15.0 \\
FSS & 0.34 & 158.42 & -1150 & 94.25 & 46594 \\
TSS & 31.9 & 75.89 & -459.72 & 95.37 & 238 \\
VSS & 40.61 & 70.75 & -419.12 & 97.01 & 174 \\
\hline
\end{tabular}
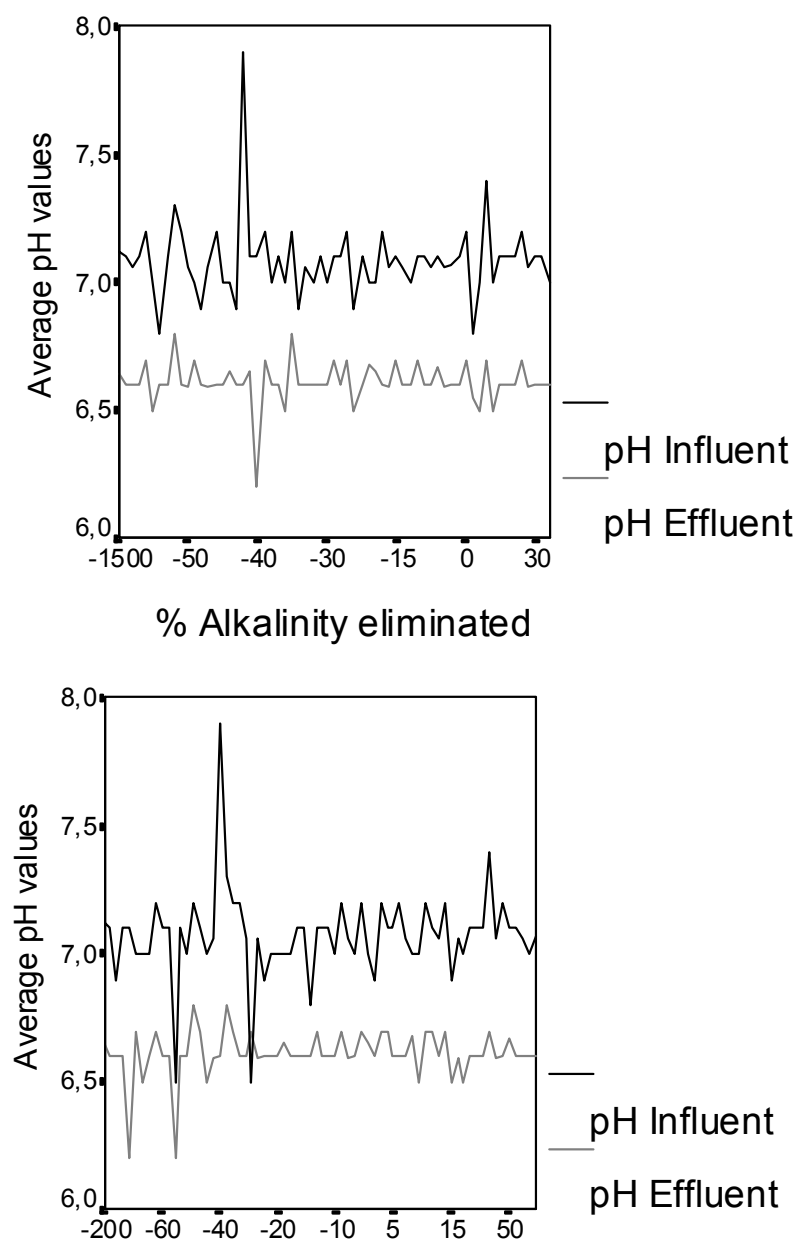

$\%$ Volatile Acidity Eliminated

Figure 2

Average $\mathrm{pH}$ values versus elimination of alkalinity and volatile acidity
Calculations were done using the stepwise technique with a critical level probability of 0.05 ( $95 \%$ confidence) for accepting a new independent variable in equation and with a level of $0.10(90 \%$ confidence) for rejecting a variable, previously selected. The program (Norusis, 1990) provides the multiple correlation coefficient $\mathrm{R}$, defined in the following form:

$\mathrm{R}^{2}\left(\mathrm{Y}, \mathrm{X}_{1}, \mathrm{X}_{2}, \mathrm{X}_{3}, \ldots\right)=\frac{\text { Variance of } \mathrm{Y} \text { explained by the equation }}{\text { Total variance of } \mathrm{Y}}$

and also permits obtaining predicted values of the function and drawing dispersion graphs to appreciate the quality of the adjustment.

\section{Discussion}

A brief account of the operational data, supplied by COPASA on the Nova Pampulha treatment plant, is shown in Table I. The great variability of some parameters (especially bacterial counts) as compared with the constancy of others ( $\mathrm{pH}$ and temperatures) is evident.

The usual behaviour is elimination of oils, organic matter and settleable or suspended solids, though increases in these parameters were sometimes observed and attributed to operational defects of the plant. An increase in ammonium salts, total nitrogen and phosphates due to degradation of organic matter or solubilisation of compounds present in suspended solids, was also found.

For the rest of the parameters, the occurrence of elimination or increase should be due to fluctuations derived from the sampling procedure or to episodes of defective operation of the UASB reactor, as a consequence of failure in granulation.

Secondly, temporal evolution of the Nova Pampulha plant can be discussed by means of graphical representations against time of process parameters, acid-base equilibrium data, inorganic or organic constituents and solids (settleable or suspended). Figure 1 shows temporal evolution of some parameters.

During the first 50 weekly samplings flows increased considerably due to the connection of additional collectors. Afterwards the flow oscillated in the range of 12 to $14 \mathrm{\ell} / \mathrm{s}$, perhaps due to seasonal variations. The evolution of hydraulic retention time thus 

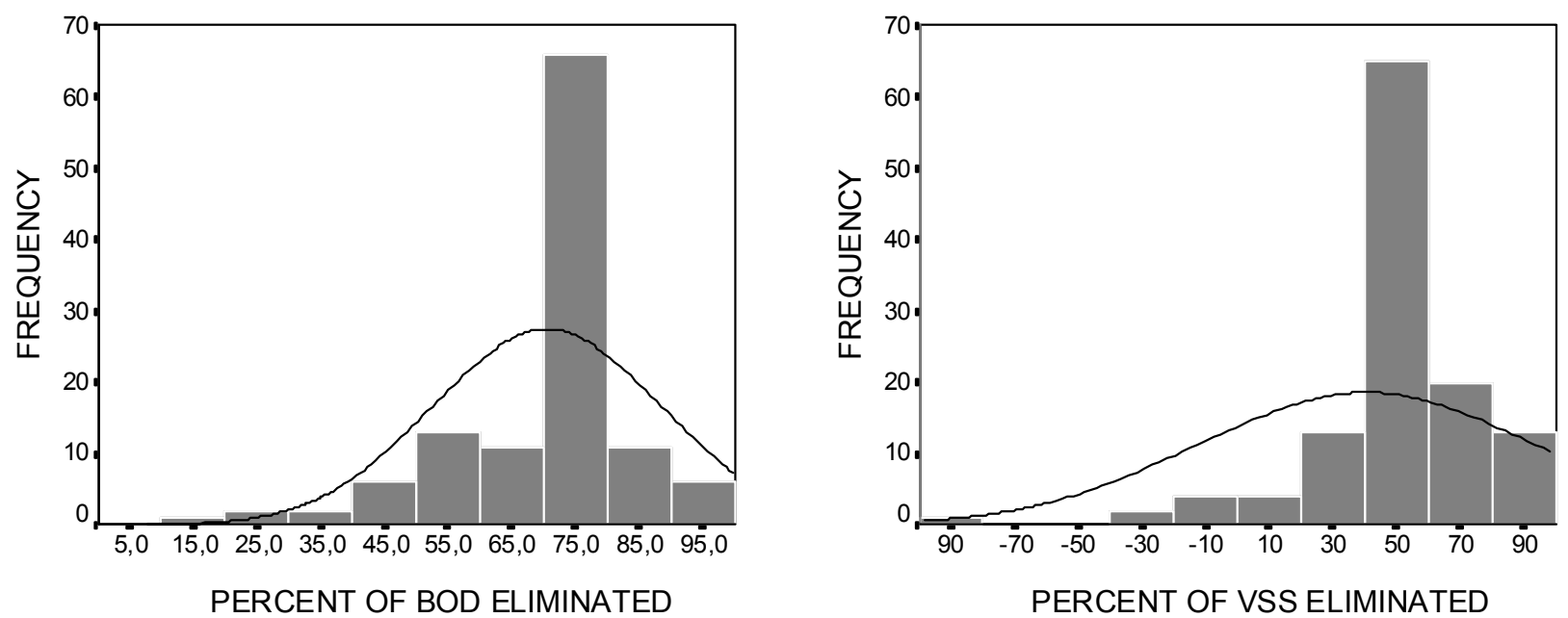

Figure 3

Histograms of percentages of elimination of $B O D$ and VSS, including normal curve for comparison
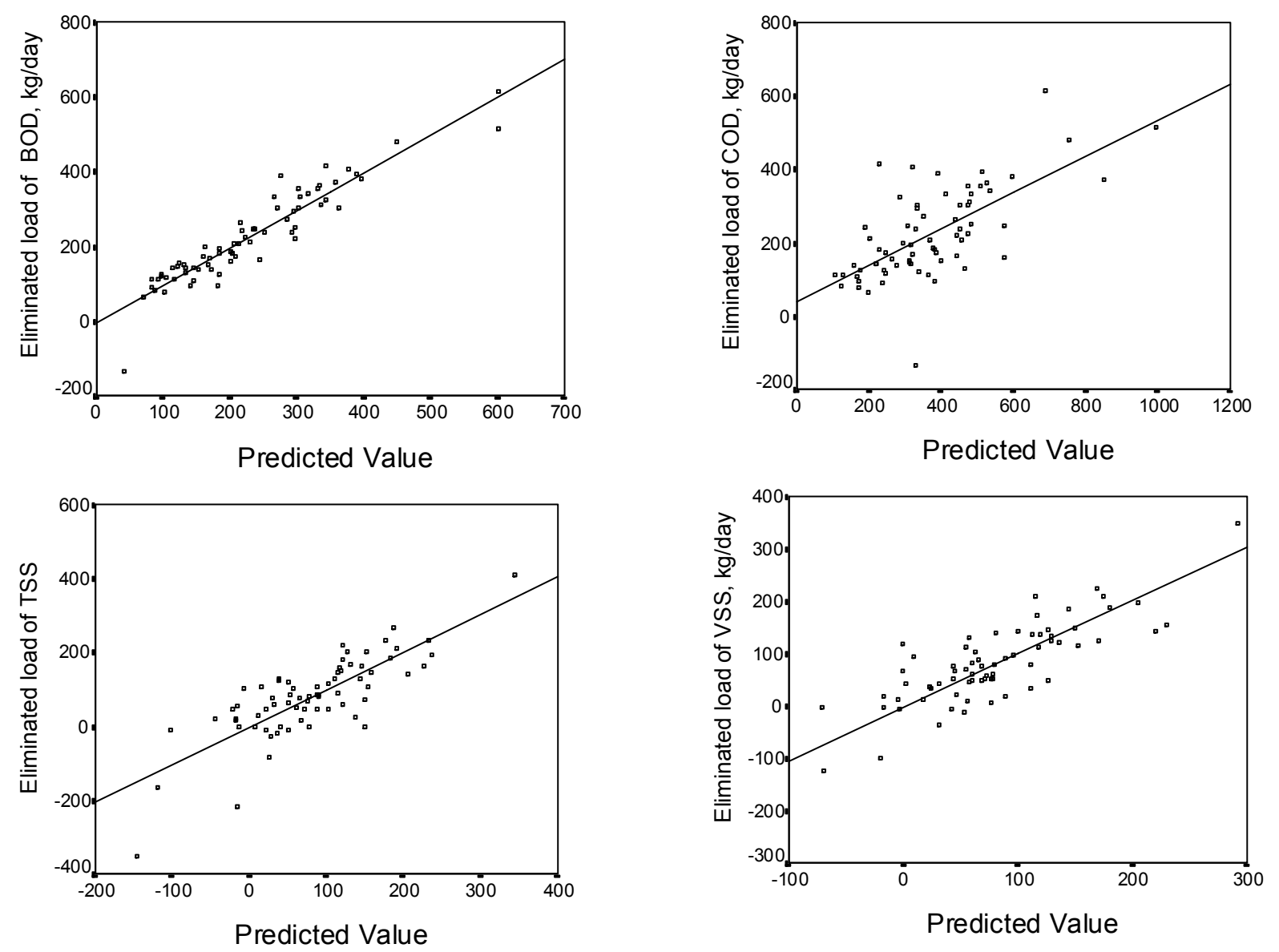

Figure 4

Comparison of some eliminated constituent loads with values predicted by multiple linear regression

showed an inverse trend.

A considerable decrease in organic matter is evident, reflected in the reductions of BOD and COD in the effluents. Elimination is slightly greater in the case of BOD and has relative maxima and minima, which suggests a seasonal dependency. In some cases, the values of elimination are negative, i.e. increases occur in the effluents, which can be attributed to deficient operation of the UASB reactor, due to possible failures in granulation.
The temporal evolution of total suspended solids shows a considerable reduction in the effluent because of elimination during the treatment. A seasonal dependency seems to exist, illustrated by maximal and minimal values for influent and effluent. Finally there are some data outside the adjusted curves, probably due to the sampling method or to treatment failures. Analogous considerations could be made on the evolution of volatile suspended soils, not shown in Fig. 1. 


\begin{tabular}{|c|c|c|c|}
\hline \multirow{15}{*}{ 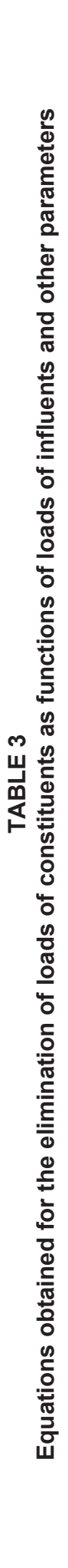 } & \multirow{3}{*}{\multicolumn{2}{|c|}{ 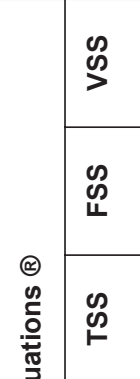 }} & 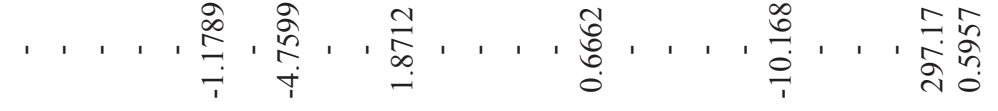 \\
\hline & & & 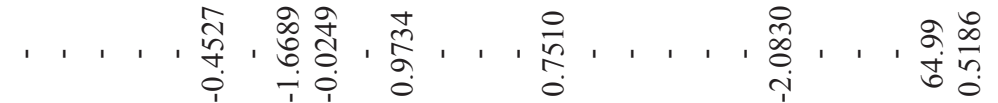 \\
\hline & & & 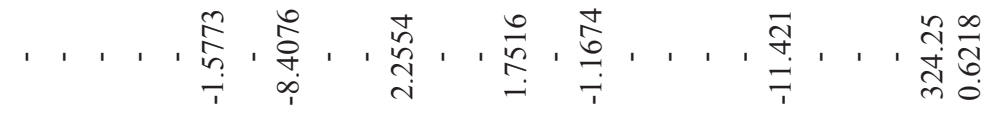 \\
\hline & $\begin{array}{l}\frac{\Xi}{0} \\
\frac{0}{\infty} \\
\frac{0}{\infty}\end{array}$ & 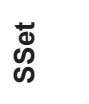 & 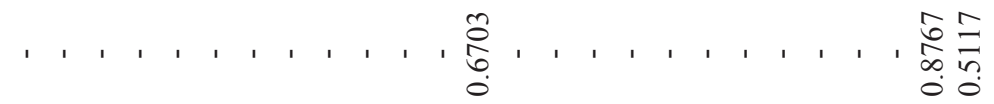 \\
\hline & $\begin{array}{l}\frac{5}{2} \\
\frac{\Phi}{0}\end{array}$ & $\begin{array}{l}\frac{\pi}{0} \\
\stackrel{5}{5} \\
\mathbf{z}\end{array}$ & 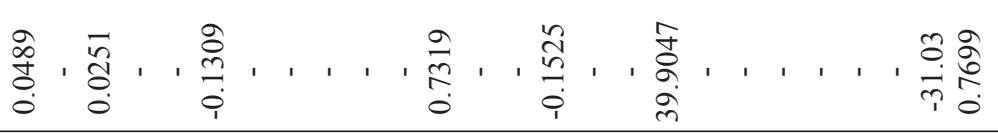 \\
\hline & $\frac{\vec{\varepsilon}}{\stackrel{\vec{g}}{\Xi}}$ & $\sum_{i}^{\frac{I_{1}^{\prime}}{2}}$ & 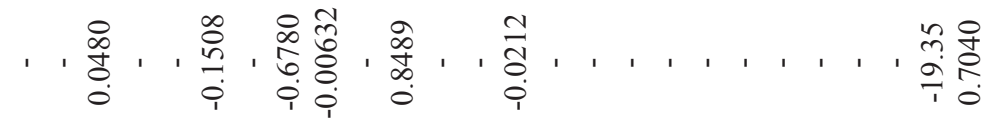 \\
\hline & 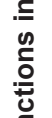 & 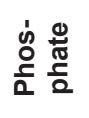 & 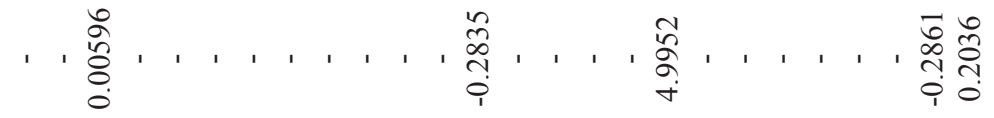 \\
\hline & 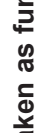 & 엉 & 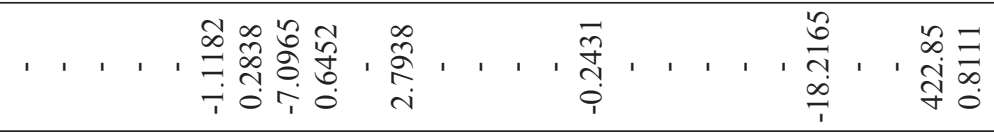 \\
\hline & 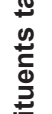 & Оิ & 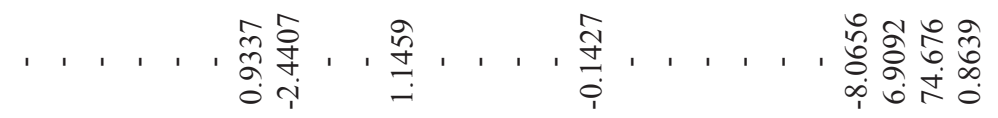 \\
\hline & 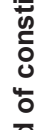 & $\begin{array}{l}\frac{0}{0} \\
\frac{0}{\frac{0}{c}} \\
\end{array}$ & 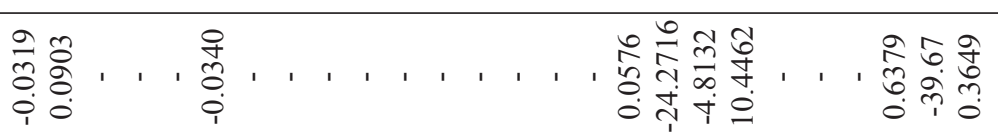 \\
\hline & 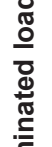 & 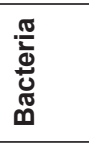 & 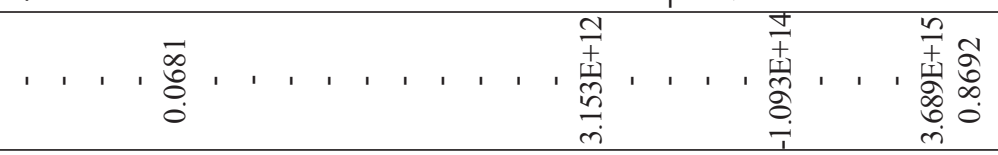 \\
\hline & 喜 & 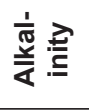 & 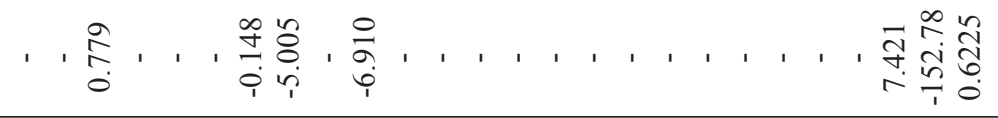 \\
\hline & & $\frac{\mathbb{3}}{\frac{3}{0}}$ & 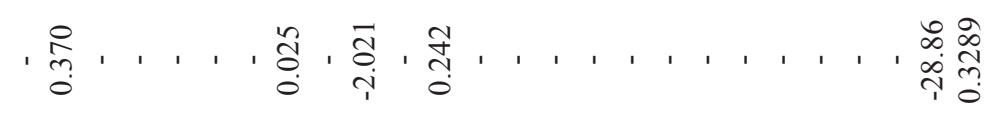 \\
\hline & & $\bar{o}$ & 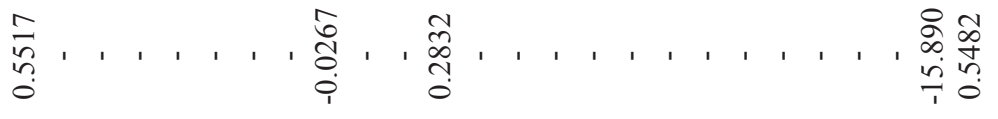 \\
\hline & & 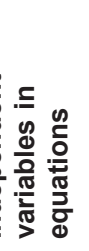 & 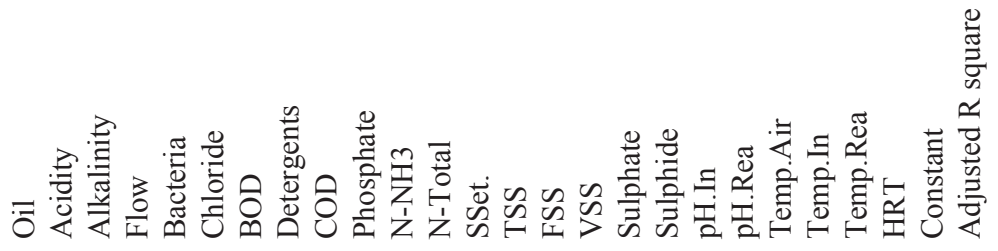 \\
\hline
\end{tabular}

The percentages of elimination of constituent loads (or increase with negative sign) are analogously summarised in Table 2. The observation of data permits the authors to suggest that:

- Most of the parameters were measured on composite samples, made up by 24 equal aliquots accumulated over $24 \mathrm{~h}$. Therefor influent and effluent composite samples are made up at sepa- rate intervals equal to hydraulic retention times and therefore, strictly speaking, they will not be comparable. This fact can probably justify small differences in some cases and leads to increases instead of elimination in the treatment. This is not applicable to settleable solids (measured in situ twice a day and expressed later as an average for the sample) or bacteria (only one counting per month with $24 \mathrm{~h}$ composite samples). 
- The minimal and some mean values of percentages of elimination of constituent loads are negative and this supposes an increase in constituents. As the maximum values are always positive, the standard deviations may be quite high. When the mean value is negative, a negative $\mathrm{CV}$ is thus obtained. If the mean value is close to zero, especially for FSS elimination, a very high $\mathrm{CV}$ is calculated.

- For volatile acidity and alkalinity, increase and elimination were observed with a mean increase in both parameters. No clear relationship between the $\mathrm{pH}$ values of influents and effluents was observed (as shown in Fig. 2), where a slight decrease in $\mathrm{pH}$ is evident as a consequence of UASB operation, probably due to the evolution of carbon dioxide.

- Elimination of organic matter and solids occurs generally as a consequence of the anaerobic treatment, but there are also increases in some cases. Therefore the cases in which increases in such constituents occur should in all probability, be attributed to deficient plant operation accompanied by leaching of suspended solids, organic matter and even of bacteria to the effluent. This agrees with the fact that the most frequent defect in the operation of a UASB reactor is granulation failure (Mergaert et al., 1992). When the plant is operating well the efficiency is comparable to data published in the literature for the same (Van Haandel et al., 1993; Vieira et al., 1994) or different type (Barbosa Correa et al., 2002) of biological treatment in Brazilian wastewater plants. The histograms included in Fig. 3 for the percentages of elimination of BOD and VSS show that the more frequent cases are close to $75 \%$ and $50 \%$, respectively. The number of cases with inefficient plant operation are less than $20 \%$.

- Special attention must be given to the cases of nitrogen and phosphorus derivatives. An increase in the concentrations of total and ammonia nitrogen and phosphates in the effluents is observed. It must be emphasised firstly that the mean concentrations of total nitrogen and phosphates in influents and effluents, shown in Table 1, are approximately equal. Therefore the increase, instead of elimination, found for these constituents, can be attributed to the sampling procedure or to small amounts of constituents originating in the anaerobic treatment, perhaps due to nitrate or nitrite reduction to ammonia compounds (and measured then as Kjeldahl total nitrogen) or to the conversion of the organic compound phosphorus to phosphate, measured in the effluent.

- The increase in ammonia nitrogen can be attributed to the fact that, during UASB treatment, mineralisation of organic nitrogen compounds, with conversion mainly to ammonia salts, was achieved.

- Finally, in the case of chloride, increase or elimination is observed and must be attributed to fluctuations in the sampling procedure, because the average chloride values of the influent and effluent are almost equal, as shown in Table 1.

The study on the Nova Pampulha plant was completed by obtaining equations by means of multiple linear regression that permit the estimation of the elimination of constituents as functions of process parameters and influent constituent loads, as possible independent variables. Significant equations at the 0.050 level $(95 \%$ of confidence) were obtained in all cases. Table 3 contains the coefficients of obtained equations and the explained variances which range from $20.36 \%$ for phosphate to $86.92 \%$ for bacteria. The quality of estimation obtained by multiple linear regression is shown in Fig. 4 for the elimination of some constituent loads. Those cases in which increases instead of elimination were observed must be again attributed to the sampling method or to inefficient operation of the UASB plant.

The observation of coefficients in the equations included in Table 3 suggests that the elimination of organic matter and suspended solids may be associated with these constituent loads and ammonia nitrogen in the influents, while the increase of effluent constituent loads seems to be associated with chloride and detergent in the influents and high temperatures.

\section{Final considerations}

As a consequence of this study, based on data of the Nova Pampulha wastewater plant, in the metropolitan region of Belo Horizonte (Minas Gerais, Brazil) containing a UASB reactor, two final remarks can be made :

This work has confirmed that, if the plant is operating correctly, its efficiency is comparable to that of other Brazilian wastewater plants using the same or different type of biological treatment. During the period of this research (January 1998 to June 2000, namely 124 weeks) inefficient plant operation was observed for less than $20 \%$ of the time, despite the great variability in flow and composition of influent.

The use of multiple linear regression has permitted the authors to obtain equations for estimating the elimination of constituent loads as functions of process parameters and constituent loads in the influents as independent variables, and to suggest the influent constituents and process parameters associated with either elimination of effluent organic matter or suspended solids during efficient plant operation, or increases, probably due to granulation failure in the UASB reactor.

\section{Acknowledgement}

We wish to thank the Brazilian Companhia de Saneamiento de Minas Gerais, COPASA, for providing the facilities for the elaboration of this work, which forms part of the Ph.D thesis of SMB Barbosa Correa.

\section{References}

BARBOSA CORREA SMB, RUIZ E and ROMERO F (2002), Comparison of Nova Pampulha UASB wastewater plant with another Brazilian stations, Congreso Mediterráneo de Ingeniería Química, Expoquimia, Barcelona, Spain.

CALVO F (1978) Estadística aplicada. Ediciones Deusto SA, Bilbao.

CHERNICHARO CAL (1997) Princípios do Tratamento Biológico de Águas Residuárias - Reatores Anaerobios . Volume 5 - Departamento de Engenharia Sanitária e Ambiental - DESA, UFMG. 246 pp.

FERRÁN M (1996) SPSS para Windows. Programación y análisis estadístico. Serie McGraw-Hill de Informática. McGraw-Hill. Madrid.

FUNDAÇÃO IBGE (2000) Brasil. www. ibge.gov.br

LETTINGA G, FIELD J, VAN LIER JB, ZEEMAN G and HULSHOFF POL LW (1997) Advanced anaerobic wastewater treatment in the near future. In: Advanced Wastewater Treatment: Nutrient Removal and Anaerobic Processes. Water Sci. Technol. 35 (10) 5-12.

LÓPÈZ JN and IZA J (1998) UASB Tecnology application for the treatment of the municipal wastewater at the city of Managua, Nicaragua. In V Taller y Seminario Latinoamericano Tratamiento anaerobio de aguas residuales. Viña del Mar, Chile.

MERGAERT K, VANDERHAEGEN B and VERSTRAETE W (1992) Review paper - Applicability and trends of anaerobic pretreatment of municipal wastewater. Water Res. 6 (8) 1025-1033.

NORUSIS MJ (1990) SPSS/PC+ Statistics 4.0. SPSS Inc., Chicago, EE.UU. 
SPSS para Windows (Versión 6.0.1). SPSS Inc., 1989 - 1993. Licencia para UPV/EHU : 8781.

STANDARD METHODS (1999) Standard Methods for the Examination of Water and Wastewater (20th edn.). Edited by Greenberg, Clesceri and Eaton. APHA, AWWA and WPCF.

VAN HAANDEL AC and LETTINGA G (1994) Tratamento Anaeróbio de Esgotos - Manual para Regiões de Clima Quente. Epgraf, Campina Grande, $210 \mathrm{pp}$.

VAN HAANDEL AC, CATUNDA AF, OLIVEIRA MG and SOUZA JT (1993) Influência do tempo de permanência sobre o desempenho de reatores anaeróbios de fluxo ascendente. $17^{\circ}$ Congresso Brasileiro de Engenharia Sanitária e Ambiental.

VIEIRA SMM, CARVALHO JL, BARIJAN FPO and RECH CM (1994) Application of the UASB technology for sewage treatment in a small community at Sumaré, São Paulo State. Water Sci. Technol. 30 (12) 203-210.

VON SPERLING M(1995) Princípios do Tratamento Biológico de Águas Residuárias. Volume 1. Introdução à qualidade das águas e a o tratamento de esgotos. Dep. de Engenharia Sanitária e Ambiental DESA, UFMG, $243 \mathrm{pp}$. 